\title{
The onset of the assembly of Pangaea in NW Iberia: Constraints on the kinematics of continental subduction
}

\author{
Rubén Díez Fernández a,*, José R. Martínez Catalán ${ }^{\text {a }}$, Ricardo Arenas ${ }^{\text {b }}$, Jacobo Abati ${ }^{\text {b }}$ \\ a Departamento de Geología, Universidad de Salamanca, 37008 Salamanca, Spain \\ ${ }^{b}$ Departamento de Petrología y Geoquímica and Instituto de Geología Económica, Universidad Complutense/Consejo Superior de Investigaciones Científicas, 28040 Madrid, Spain
}

Keywords:

Assembly of Pangaea

Continental subduction kinematics

Tect onics

NW Iberia

\begin{abstract}
A B S T R A C T
Excellent exposures of high-pressure rocks developed in a Variscan continental subduction system outcrop in NW Iberia. The kinematic criteria provided by the high-pressure metamorphic fabrics can be used to infer tectonic flow within the deep sections of this system. The dominant trend of the ductile flow is oblique to that of the orogenic belt, indicating oblique continental subduction. Its azimuth, a few tens of degrees clockwise relative to the orogenic trend, suggests dextral transpression between Gondwana and Laurussia during continental subduction that took place at the Upper Devonian, and provides a consistent kinematic reference for the earliest assembly of Pangaea in NW Iberia.
\end{abstract}

\section{Introduction}

The oldest evidence on the plate kinematics of a given continentcontinent assembly lies in its continental subduction record preceding collision, and the high- to ultrahigh-pressure (HP/UHP) belts so formed are witness of such processes. Exhumed continental blocks develop a strong overprint of the subduction record as they return to shallower lithospheric levels (e.g. Ring et al., 2007; Zhang et al., 2009; Hacker et al., 2010), where such evidence is mostly preserved in small and disconnected lenses (e.g. eclogite pods; Teyssier et al., 2010), commonly as mineral relicts within a dominant low- to medium-pressure metamorphic matrix. Indeed, recent modeling predicts large-scale nappe-folding during the process (e.g. Gerya et al., 2002; Warren et al., 2008) that would distort any former geological record (Díez Fernández et al., 2011a). For these reasons, unraveling the earliest kinematic events in ancient collisional orogenies is one of the most critical topics in tectonics, and requires significant structural and metamorphic insights.

The supercontinent Pangaea assembled from the collision between Gondwana and Laurussia, following the closure of the Rheic Ocean during the Upper Paleozoic (Matte, 1986; Scotese, 1997; Stampfli and Borel, 2002; Martínez Catalán et al., 2009). The Variscan Belt represents

\footnotetext{
* Corresponding author. Tel.: + 34923 294488; fax: + 34923294514.

E-mail addresses: georuben@usal.es (R. Díez Fernández), jrmc@usales (J.R Martínez Catalán), arenas@geo.ucm.es (R. Arenas), abati@geo.ucm.es (J. Abati).
}

that part of this amalgamation preserved in Europe, which started with the subduction of the Gondwana plate in the Upper Devonian (e.g. Schulmann et al., 2005; Ballèvre et al., 2009; Abati et al, 2010). Kinematic data for this event are lacking. Variations in the PT conditions of the first HP metamorphic event along this margin indicate a westdipping (present coordinates) polarity for the continental subduction in NW Iberia (Martínez Catalán et al., 1996). There is a lack of consistent indicators of along-strike components during the subduction, so ideas about the early relative plate movement between the two main landmasses involved in the assembly of Pangaea are highly speculative (e.g. Arenas et al, 2009).

Exposures of well-preserved Variscan HP rocks are rare, but where they occur they provide evidence for the kinematics of continental subduction. We present in situ kinematic criteria from the best outcrops of eclogite rocks developed in the section of the Variscan subduction system exposed in NW Iberia, Spain. The data are accompanied by a detailed field analysis and a regional tectonometamorphic synthesis in order to constrain their plate tectonic significance.

\section{Geologic setting}

The allochthonous complexes of NW Iberia comprise a nappe stack of allochthonous units, in which the Neoproterozoic and Paleozoic geodynamic evolution of the northern peri-Gondwanan realm is preserved as a collage of exotic terranes that delineate a piece of the suture zone of the Rheic Ocean (Fig. 1; Martínez Catalán et al., 2009). The peripheral and outermost domains are placed on top. The uppermost thrusts consist of an imbricated Cambro-Ordovician continental 


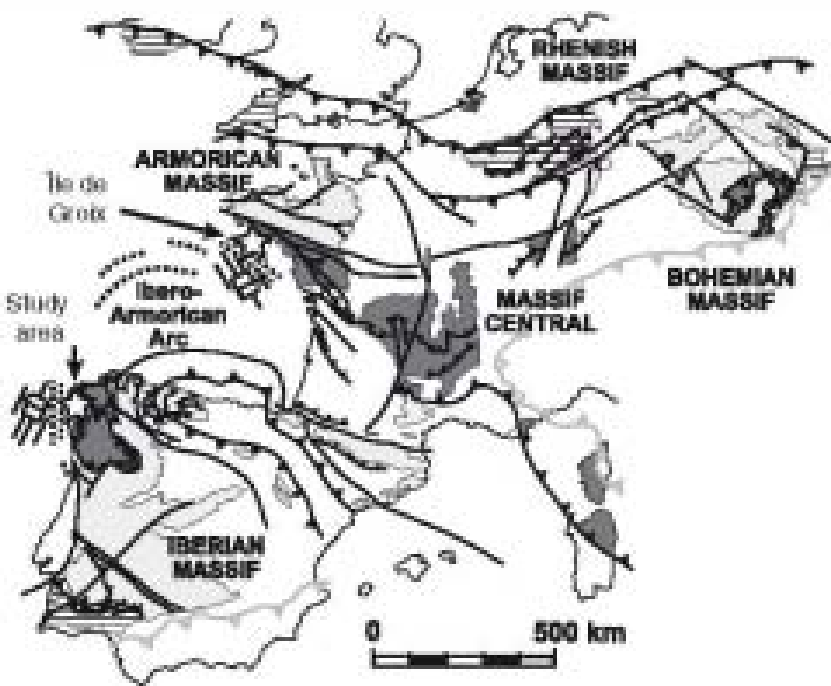

VARISCAN BELT
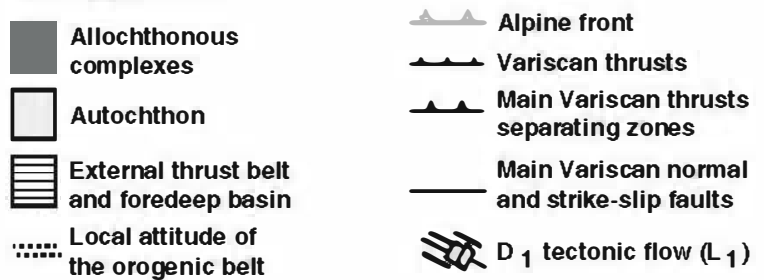

Fig. 1. Location of the study area in the Variscan belt. The orientation of $D_{1}$ tectonic flow in relation to the trend of the orogenic belt is shown. Data from NW Iberia (published in this article) and from Île de Groix, France (Philippon et al., 2009).

arc detached from Gondwana (Abati et al., 1999; Gómez Barreiro et al., 2007). The middle units are ophiolitic, and represent vestiges of Rheic Ocean lithosphere (Sánchez Martínez et al., 2009). The basal units outline the most external part of the Gondwana margin (Díez Fernández et al., 2010; Díez Fernández et al., 2011b). The allochthonous pile rests on top of a parautochthonous imbricate thrust sheet that occupies an intermediate position in the regional structural pile, separating the allochthonous complexes from the autochthonous series of the Iberian Massif (Martínez Catalán et al., 2007).

Variscan deformation started in the basal units, and developed under HP/UHP conditions ( $D_{1}$; Díez Fernández et al., 2011a). This event records the subduction of Gondwana beneath an accretionary complex and Laurussia (Fig. 2), and is the focus of this article.

\section{The relicts of continental subduction}

The basal units include large, lens-shaped, orthogneiss massifs surrounded by albite-bearing schists and paragneisses, and altemating with mafic rocks (Fig. 3a). The metamorphic conditions reached within the subduction wedge range between blueschist and eclogite facies, whereas the early exhumation $\left(D_{2}\right)$ developed under amphibolite to

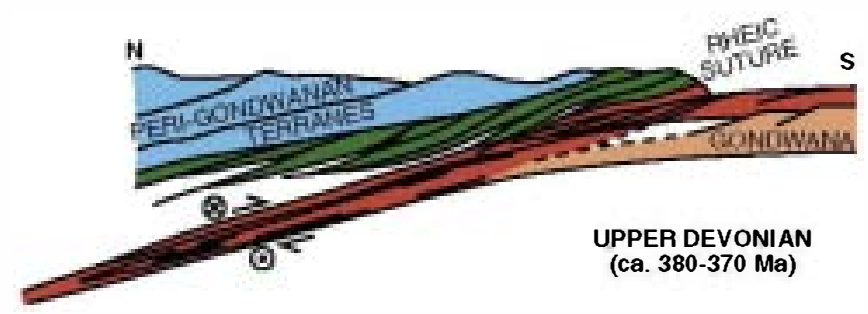

Fig. 2. Continental subduction model for the northern Gondwana margin exposed in NW Iberia. greenschist facies conditions (Rodríguez et al., 2003). The HP mineral assemblage $\left(S_{1}\right)$ in the metasedimentary rocks consists of quartz + phengite + garnet \pm rutile \pm epidote in the lower structural sections (Diez Fernández et al., 2011a), and chloritoid + garnet \pm glaucophane + phengite + paragonite + chlorite + epidote + rutile + illmenite + quartz in the upper sections (López-Carmona et al., 2010). These assemblages usually occur as mineral trails within syn-exhumation albite porphyroblasts (Arenas et al., 1995), and have not been considered for linematic analysis.

A foliation developed in most of the orthogneisses during the earliest stages of exhumation (Díez Fernández et al., 2011a), but relict coronitic garnets in igneous biotite provide evidence for the subduction event (Gil Ibarguchi, 1995). More importantly, nonretrogressed HP fabrics can be found in tonalitic orthogneisses, which also enclose subconcordant lenses of eclogite. Both the tonalitic orthogneisses and the eclogites are exposed together in the Malpica-Tui Complex north of the Fervenza reservoir (Fig. 3a and b), where they represent large bodies, several hundreds of meters thick that escaped retrogression during exhumation.

The $D_{1}$ assemblage $\left(S_{1}\right)$ of the tonalitic orthogneisses includes omphacite + gamet + quart $z+$ zoisite + phengite + rutile + kyanite \pm apatite \pm zircon, and defines a tectonic banding in which quartz-rich layers alternate with melanocratic layers and lenses with nemato-lepidoblastic texture (Fig. 4a). The eclogites are fine- to medium-grained rocks with grano-nematoblastic texture. $\mathrm{S}_{1}$ consists of garnet + omphacite + zoisite + rutile + phengite + quartz + kyanite (Fig. $4 b$ ). $S_{1}$ is the main foliation within the HP bodies, and its minerals define a mineral and a stretching lineation $\left(L_{1}\right)$. These rock types provide clues to the metamorphic and deformational conditions at P $>2$ GPa (2.4$2.6 \mathrm{GPa}$ and $615^{\circ} \mathrm{C}$; Rodriguez et al., 2003), and the age of the oldest dated Variscan deformation ( $372 \pm 3 \mathrm{Ma}$; Abati et al., 2010). In the tonalitic orthogneisses, chlorite, white mica and epidote may occur within $D_{1}$-garnet, whereas in the eclogites, glaucophane may be rapped within $\mathrm{D}_{1}$-garnet (Fig. $4 \mathrm{c}$ ). Such inclusions witness previous colder conditions in a HP prograde P-T-t path, suggesting that $S_{1}$ represents a fossil relict of the continental subduction.

\section{Kinematic criteria and structural framework}

The sense of rotation of the vorticity vector of the $D_{1}$ tectonic flow was determined by using offset mesoscopic and microscopic features in $S_{1}$. Kinematic criteria include $\sigma$-type porphyroclasts and lenses, asymmetrical boudinage, SC composite foliation or $\mathrm{C}^{\prime}$ fabrics, and intrafolial asymmetrical recumbent folds (Fig. $4 \mathrm{~d}$ and e). $\mathrm{S}_{1}$ is a flat-lying foliation bent into open upright synforms (see local orientation in Fig. 3a) and shows consistent top-to-the-NE shear-sense (Fig. $3 \mathrm{C}$ ). $\mathrm{D}_{1}$ folds axes have NW-SE trends $\left(120^{\circ} / 16^{\circ}\right)$ and are perpendicular to $L_{1}$, the mean trend of which in the tonalitic orthogneisses and eclogites is $30^{2} / 21^{2}$ (Fig. 3c), thus constraining the $D_{1}$ tectonic flow to a NE-SW vector.

The early exhumation of the basal units was driven by large foldnappe structures $\left(D_{2}\right)$. Progressive exhumation started with the Fervenza thrust, which was followed by the propagation towards the foreland of a rain of recumbent folds, and replaced by the Ialin-Forcarei thrust (Fig. 3d; Díez Femández et al., 2011a). These events preceded the emplacement of the suture zone onto the Gondwana mainland by outof-sequence thrusting ( $D_{3}$; Martínez Catalán et al., 2002). Crustal thickening was followed by the gravitational collapse of the collisional wedge $\left(D_{4}\right.$; Gómez Barreiro et al., 2010; Díez Fernández et al., accepted), wrench tectonics and upright folding $\left(D_{5}\right)$, and oroclinal bending (Weil et al., 2000). In the light of such a complex scenario, the interpretation of the $D_{1}$ flow relies on whether or not the relative orientations of the indicators were modified during the exhumation.

The tonalitic orthogneiss bodies occur in the hanging wall of the Fervenza thrust, in the normal limb of a $\mathrm{D}_{2}$ fold (Fig. 3b), in a domain free from strike-slip shear zones, and at the hinge zone of a late, open upright synform. Although the tonalitic orthogneisses are surrounded 


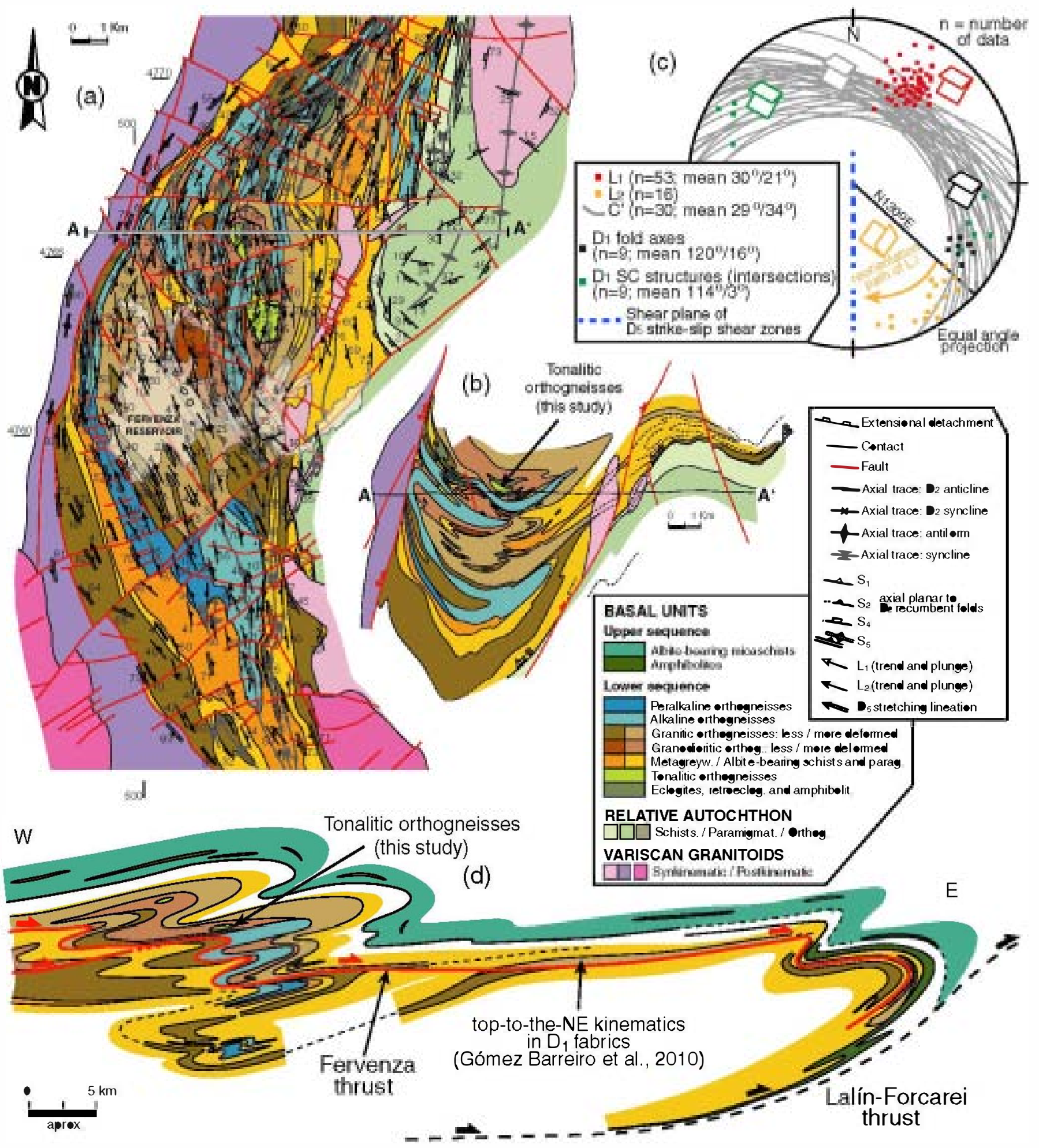

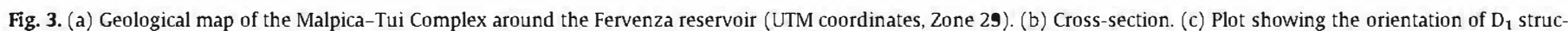

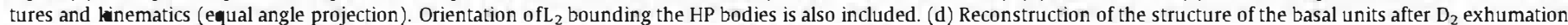
event showing the position of the studied tonalitic orthogneisses (after Díez Fernández et al., 2011a).

by mylonitic felsic orthogneisses with a penetrative $D_{2}$ fabric $\left(S_{2}\right.$; topto-the-SE and -ESE), $\mathrm{L}_{1}$ and the stretching lineation developed during $\mathrm{D}_{2}\left(\mathrm{~L}_{2}\right)$ are usually oriented at very high angles to one another and may be perpendicular (Fig. 3a and c). Subsequent deformation phases did not affect this section of the Malpica-Tui Complex, which in this part of the Ibero-Armorican arc has a N-S orientation.

\section{Discussion}

No significant ductile reorientation of $\mathrm{D}_{1}$ linear fabrics related to folding and/or deflection by ductile shearing has been observed in the tonalitic orthogneisses north of the Fervenza reservoir. This is supported by the near perpendicular relationship between $D_{1}$ fold 

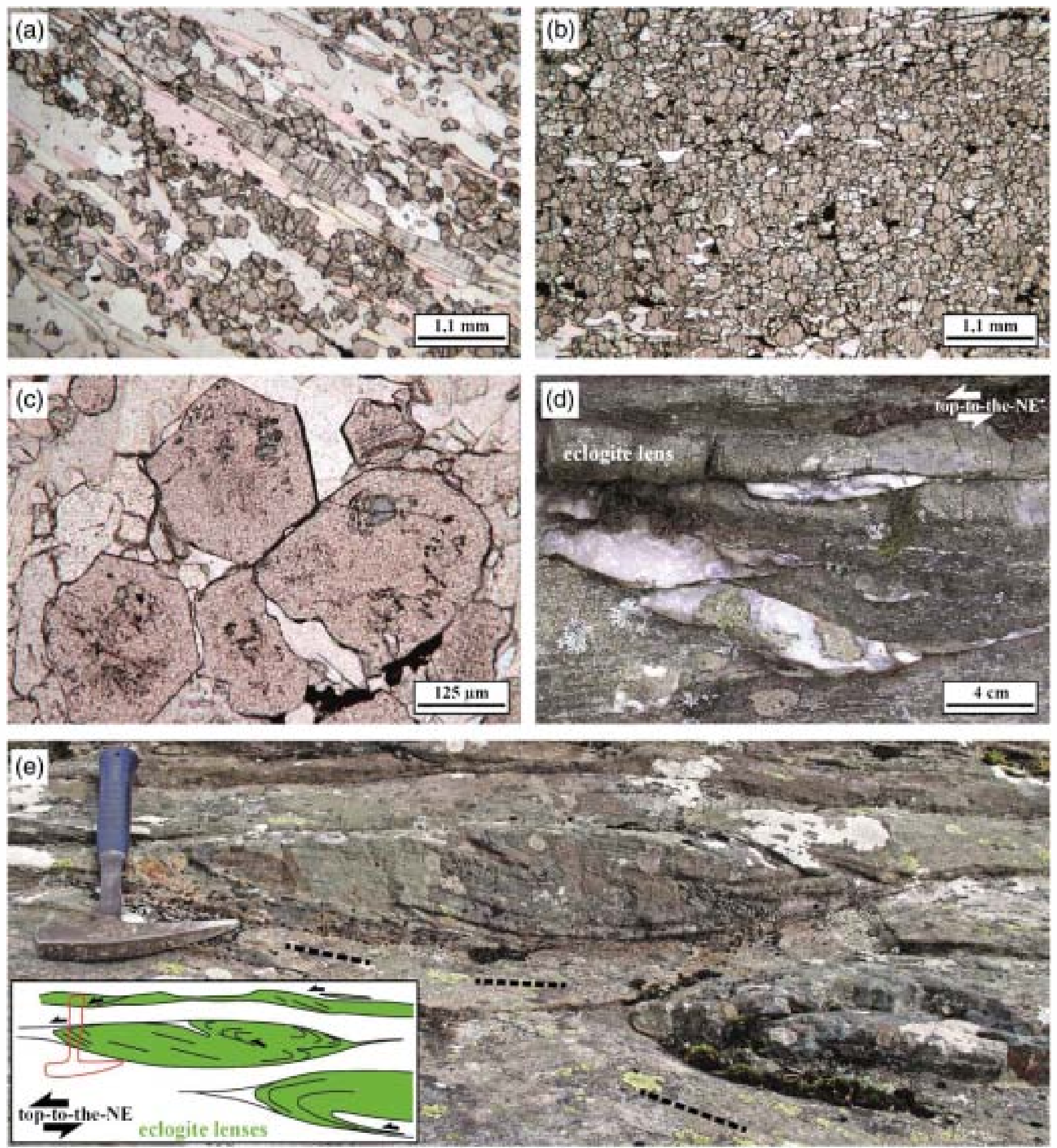

Fig. 4. (a) $S_{1}$ in the tonalitic orthogneisses. (b) $S_{1}$ in fine-grained eclogites enclosed in tonalitic orthogneisses. (c) Glaucophane relicts in $D_{1}$ garnets from eclogite. (d) Sigmoidal boudinage in quartz ribbons and segregates from tonalitic orthogneisses. (e) Structures preserved in eclogite lenses enclosed in tonalitic orthogneisses. See sketch for best visualization of kinematic criteria (sigmoidal boudinage with $\sigma$-type asymmetry boudinage and intrafolial folds, $\mathrm{C}^{\prime}$ fabrics, and S-C composite foliation). Stretching lineation ( $\mathrm{L}_{1}$ ) is shown as black dashed lines. The picture is normal to $\mathrm{D}_{1}$ fold axes.

axes and $\mathrm{L}_{1}$ (Fig. 3c). The data suggest passive rotation of the large, undeformed domains embedded in a viscous media. But a detailed 3D analysis of two large orthogneissic massifs in the southern part of the Malpica-Tui Complex indicate that the same regional NNESSW stretching during $D_{1}$ occurred there (Díez Fernández and Martínez Catalán, 2009). That study was carried out 80 to $95 \mathrm{~km}$ to the south of the Fervenza reservoir, and the fact that the main $D_{1}$ stretching direction is the same in both areas allows us to discard the possibility of large passive rotations. On the other hand, the analysis of quartz c-axis fabrics of tectonites provided a similar attitude for $D_{1}$ flow in the continuation of the basal units in the Órdenes Complex, to the east (Gómez Barreiro et al., 2010). 

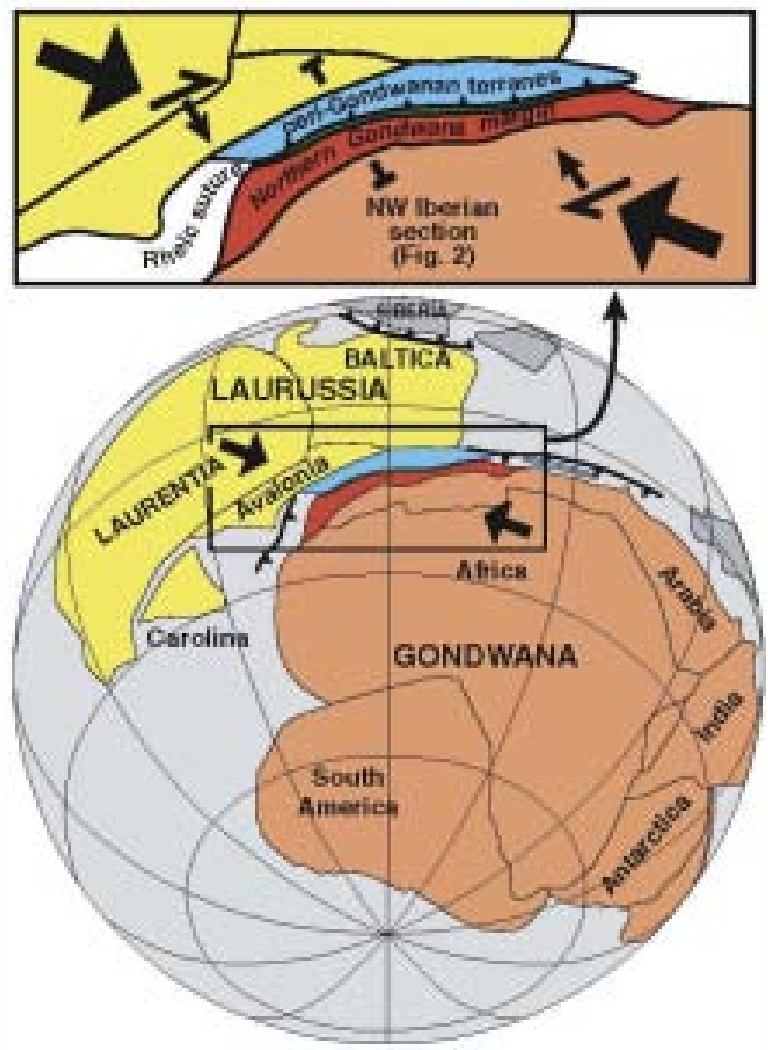

UPPER DEVONIAN (ca. 380-370 Ma)

Fig. 5. Suggested global plate kinematics during the Upper Devonian. Continental mass distribution based on Winchester et al. (2002) and Gómez Barreiro et al. (2007).

Although post-subduction mylonitization deeply affected the Malpica-Tui Complex, modifying and reorienting nearly all of the earlier planar and linear fabrics towards their respective flow planes (e.g. $L_{2}$ toward $D_{5}$ shear zones; Fig. $3 a$ and $c$ ), we conclude that the $\mathrm{NE}-\mathrm{SW}$ trend preserved in the tonalitic orthogneisses is a reasonable approximation to the original $D_{1}$ flow vectors. It must be pointed out, however, that such a trend is estimated in present coordinates, and for a section of the belt with a N-S attitude.

The same Variscan continental subduction system described here is also exposed in Île de Groix, France (Fig. 1). There, Philippon et al. (2009) reported top-to-the-SE kinematics in $\mathrm{D}_{1}$ fabrics. Coming from a small island, it is difficult to put this datum in a regional structural context since it is disconnected from the Armorican Massif. However, the Île de Groix lithologies and tectonometamorphic evolution are comparable to that of the upper sequence exposed in the basal units of NW Iberia (Díez Fernández et al., 2010), which occurs in the long, normal limb of a large $D_{2}$ fold-nappe (Diez Fernández et al., 2011a). If the structural position is equivalent in île de Groix, and the Ibero-Armorican Arc is restored to a straight trend (Weil et al., 2000), the $D_{1}$ flow in the French section becomes similar to that preserved in NW Iberia, that is, with its azimuth rotated clockwise in relation to the trend of the orogenic belt (Fig. 1).

The interpretation of stching lineations is always subject to some controversy, as its meaning may vary depending on the geometry of the shear zone (Passchier, 1998). The $\mathrm{D}_{1}$ event records very deep processes in the Variscan subduction system, where a significant component of pure shear might be expected. However, our field data support the existence of a dominant component of simple shear, since $L_{1}$ and the $D_{1}$ vorticity vector are perpendicular. We cannot disinguish between monoclinic and riclinic symmetries but, in either case, the stretching lineation would tend to point to the shear direction (Lin et al., 1998).
In a suture zone, stretching normal to its regional trend would be consistent with orthogonal subduction, whereas an oblique stretching lineation would indicate strike-slip components. The NE-SW tectonic flow of the $D_{1}$ deformation in the Malpica-Tui Complex supports a combination of normal and parallel components, acting together in this particular plate boundary instead of being partitioned in separate fault zones. We consider that the flow reported here for $\mathrm{D}_{1}$ deformation represents the coupling between the downgoing Gondwana plate and the overriding Laurussian mantle wedge in a large and wide ductile shear zone dominated by simple shear. This megastructure affected a considerable section of the subducted continental crust and developed in an oblique subduction setting with a significant component of dextral motion (Fig. 5).

\section{Acknowledgements}

The authors thank reviewers Michel Ballèvre and Brendan Murphy, as well as editor Damian Nance for many useful and constructive comments. This work was funded by research projects CGL2007-65338C02-01 and -02/BTE of the Dirección General de Programas y Transferencia del Conocimiento (Spanish Ministry of Science and Innovation), co-financed by the European Funds of Regional Development (FEDER).

\section{References}

Abati,J., Dunning, G.R, Arenas, R., Díaz García, F., González Cuadra, P., Martínez Catalán, J.R., Andonaegui, P., 1999. Early Ordovician orogenic event in Galicia (NW Spain): evidence from $\mathrm{U}-\mathrm{Pb}$ ages in the uppermost unit of the Ordenes Complex. Earth and Planetary Science Letters 165 (2), 213-228.

Abati, J., Gerdes, A., Fernández-Suárez, J., Arenas, R., Whitehouse, M.J., Díez Fernández, R, 2010. Magmatism and early-Variscan continental subduction in the northern Gondwana margin recorded in zircons from the basal units of Galicia, NW Spain. Geological Society of America Bulletin 122 (1-2), 219-235.

Arenas, R., Rubio Pascual, F.J., Díaz García, F., Martínez Catalán,J.R., 1995. High-pressure micro-inclusions and development of an inverted metamorphic gradient in the Santiago-schists (Órdenes-Complex, NW Iberian Massif, Spain) - evidence of subduction and syncollisional decompression. Journal of Metamorphic Geology 13 (2), $141-164$

Arenas, R, Sánchez Martínez, S., Castineiras, P., Jeffries, T.E., Díez Fernández, R., Andonaegui, P., 2009. The basal tectonic melange of the Cabo Ortegal Complex (NW Iberian Massif): a key unit in the suture of Pangea. Journal of Iberian Geology 35 (2), 85-125.

Ballèvre, M., Bosse, V., Ducassou, C., Pitra, P., 2009. Palaeozoic history of the Armorican Massif: models for the tectonic evolution of the suture zones. Comptes Rendus Geosciences 341 (2-3), 174-201.

Díez Fernández, R., Martínez Catalán, J.R., 2009. 3D analysis of an Ordovician igneous ensemble: a complex magmatic structure hidden in a polydeformed allochthonous Variscan unit. Journal of Structural Geology 31 (3), 222-236.

Díez Fernández, R., Martínez Catalán,J.R, Arenas, R., Abati,J., 2011a. Tectonic evolution of a continental subduction-exhumation channel: Variscan structure of the basal allochthonous units in NW Spain. Tectonics 30 (3), TC3009. doi:10.1029/ 2010TC002850.

Díez Fernández, R, Martínez Catalán, J.R., Gerdes, A., Abati, J., Arenas, R., FernándezSuárez, J., 2010. U-Pb ages of detrital zircons from the Basal allochthonous units of NW Iberia: provenance and paleoposition on the northern margin of Gondwana during the Neoproterozoic and Paleozoic. Gondwana Research 18 (2-3), 385-399.

Díez Fernández, R, Castiñeiras, P., Barreiro, J.G., 2011b. Age constraints on Lower Paleozoic convention system: magmatic events in the NW Iberian Gondwana margin. Gondwana Research. doi:10.1016/j.gr.2011.07.028.

Gerya, T.V., Stöckhert, B., Perchuk, A., 2002. Exhumation of high-pressure metamorphic rocks in a subduction channel: a numerical simulation. Tectonics 21 (6), 1056 doi: $10.1029 / 2002$ TCO01406.

Gil Ibarguchi, J.I., 1995. Petrology of jadeite metagranite and associated orthogneiss from the Malpica-Tuy allochthon (Northwest Spain). European Journal of Mineralogy 7 (2), 403-415

Gómez Barreiro, J., Martínez Catalán, J.R., Arenas, R, Castiñeiras, P., Abati, J., Díaz García, F., Wijbrans, J.R., 2007. Tectonic evolution of the upper allochthon of the Órdenes Complex (northwestern Iberian Massif): structural constraints to a polyorogenic peri- Gondwanan terrane. The evolution of the Rheic Ocean: from AvalonianCadomian active margin to Alleghenian-Variscan collision: In: Linnemann, U., Nance, RD., Kraft, P., Zulauf, G. (Eds.), Geological Society of America Special Paper, 423, pp. 315-332.

Gómez Barreiro, J., Martínez Catalán, J.R., Díez Fernández, R., Arenas, R., Díaz García, F., 2010. Upper crust reworking during gravitational collapse: the Bembibre-Pico Sacro detachment system (NW Iberia). Journal of the Geological Society 167 (4), 769-784.

Hacker, B.R., Andersen, T.B., Johnston, S., Kylander-Clark, A.R.C., Peterman, E.M., Walsh, E.O., Young, D., 2010. High-temperature deformation during continental-margin subduction \& exhumation: the ultrahigh-pressure Western Gneiss Region of Norway. Tectonophysics 480 (1-4), 149-171. 
Lin, S.F., Jiang, D., Williams, P.F., 1998. Transpression (or transtension) zones of triclinic symmetry: natural example and theoretical modelling. Continental Transpressional and Transtensional Tectonics 135, 41-57.

López-Carmona, A., Abati, J., Reche, J., 2010. Petrologic modeling of chloritoid-glaucophane schists from the NW Iberian Massif. Gondwana Research 17 (2-3), 377-391.

Martínez Catalán, J.R., Arenas, R., Abati, J., Sánchez Martínez, S., Díaz García, F., Fernández-Suárez, J., González Cuadra, P., Castineiras, P., Gómez Barreiro, J., Díez Montes, A., González Clavijo, E., Rubio Pascual, F.J., Andonaegui, P., Jeffries, T.E., Alcock, J.E., Díez Fernández, R., Iópez Carmona, A., 2009. A rootless suture and the loss of the roots of a mountain chain: the Variscan belt of NW Iberia. Comptes Rendus Geoscience341 (2-3), 114-126.

Martínez Catalán, J.R., Arenas, R., Díaz García, F., Gómez Barreiro, J., González Cuadra, P., Abati, J., Castiñeiras, P., Fernández-Suárez, J., Sánchez Martínez, S., Andonaegui, P. González Clavijo, E., Díez Montes, A., Rubio Pascual, F.J., Valle Aguado, B., 2007. Space and time in the tectonic evolution of the northwestern Iberian Massif. Implications for the Variscan belt. In: Hatcher, RD., Carlson, M.P., Mcbride, J.H., Martínez Catalán, J.R. (Eds.), 4-D Framework of Continental Crust. Geological Society of America Memoir, Boulder, Colorado, pp. 403-423.

Martínez Catalán, J.R., Arenas, R., Díaz García, F., Rubio Pascual, F.J., Abati, J., Marquínez García, J., 1996. Variscan exhumation of a subducted paleozoic continental margin: the basal units of the Ordenes Complex, Galicia, NW Spain. Tectonics 15 (1) $106-121$.

Martínez Catalán, J.R, Díaz García, F., Arenas, R, Abati, J., Castineiras, P., González Cuadra, P., Gómez Barreiro, J., Rubio Pascual, F.J., 2002. Thrust and detachment systems in the Ordenes Complex (northwestern Spain): implications for the Variscan-Appalachian geodynamics. In: Martínez Catalán, J.R., Hatcher, R.D., Arenas, R., Díaz García, F. (Eds.), Variscan-Appalachian dynamics: the building of the Iate Paleozoic basement: Geological Society of America Special Paper, pp. 163-182.

Matte, P., 1986. Tectonics and plate tectonics model for the Variscan belt of Europe. Tectonophysics $126(2-4), 329-374$

Passchier, C.W., 1998. Monoclinic model shear zones. Journal of Structural Geology 20 (8), 1121-1137.

Philippon, M., Brun, J.P., Gueydan, F., 2009. Kinematic records of subduction and exhumation in the lle de Groix blueschists (Hercynian belt; Western France).Journal of Structural Geology 31 (11), 1308-1321.
Ring, U., Will, T., Glodny, J., Kumerics, C., Gessner, K., Thomson, S., Gungor, T., Monie, P., Okusch, M., Druppel, K., 2007. Early exhumation of high-pressure rocks in extrusion wedges: Cycladic blueschist unit in the eastern Aegean, Greece, and Turkey. Tectonics 26 (2), TC2001. doi:10.1029/2005tc001872.

Rodríguez, J., Cosca, M.A. Gil Ibarguchi, J.I., Dallmeyer, RD., 2003. Strain partitioning and preservation of ${ }^{4 \bullet} \mathrm{Ar} /{ }^{39} \mathrm{Ar}$ ages during Variscan exhumation of a subducted crust (Malpica-Tui complex, NW Spain). Lithos 70 (3-4), 111-139.

Sánchez Martínez, S. Arenas, R., Fernández-Suárez, J. Jeffries, T.E., 2009. From Rodinia to Pangaea: ophiolites from NW Iberia as witness for a long-lived continental margin. Geological Society, Iondon, Special Publication 327, 317-341.

Scotese, C.R., 1997. Continental drift, 7th ed. PALEOMAP Project, Arlington, Texas. $79 \mathrm{pp}$

Schulmann, K., Kroner, A., Hegner, E., Wendt, I., Konopasek, J., Lexa, O., Stipska, P., 2005. Chronological constraints on the pre-orogenic history, burial and exhumation of deep-seated rocks along the eastern margin of the Variscan Orogen, Bohemian Massif, Czech Republic. American Journal of Science 305 (5), 407-448.

Stampfli, G.M., Borel, G.D., 2002. A plate tectonic model for the Paleozoic and Mesozoic constrained by dynamic plate boundaries and restored synthetic oceanic isochrons. Earth and Planetary Science Ietters $196(1-2), 17-33$.

Teyssier, C., Whitney, D.L, Toraman, E., Seaton, N.C.A., 2010. Iawsonite vorticity and subduction kinematics. Geology 38 (12), 1123-1126.

Warren, C.J., Beaumont, C., Jamieson, R.A., 2008. Modelling tectonic styles and ultrahigh pressure (UHP) rock exhumation during the transition from oceanic subduction to continental collision. Earth and Planetary Science Letters $267(1-2)$, $129-145$.

Weil, A.B., Van der Voo, R., van der Pluijm, B.A., Parés, J.M., 2000. The formation of an orocline by multiphase deformation: a paleomagnetic investigation of the Cantabria-Asturias Arc (northern Spain). Journal of Structural Geology 22 (6), 735-756.

Winchester, J.A., Pharaoh, T.C, Verniers, J., 2002. Palaeozoic amalgamation of Central Europe: an introduction and synthesis of new results from recent geological and geophysical investigations. Palaeozoic Amalgamation of Central Europe 201, 1-18.

Zhang, R.Y., Liou, J.G., Ernst, W.G., 2009. The Dabie-Sulu continental collision zone: a comprehensive review. Gondwana Research $16(1), 1-26$. 